\title{
Diazinon and Dursban residue in Soil at Different Applied Doses and Response of Cabbage at Different growth stages
}

\author{
*Mohammad Naushad Alam and Md Didar-Ul-Alam \\ Department of Soil, Water and Environment, University of Dhaka, Bangladesh
}

Submission: August 13, 2017; Published: September 06, 2017

*Corresponding author: Mohammad Naushad Alam, Department of Soil, Water and Environment, University of Dhaka, Dhaka-1000, Bangladesh, Tel: +880-1827-703148; Email: naushaddu@gmail.com

\begin{abstract}
An experiment was conducted at Experimental Field of BCSIR, Dhaka during winter season 2008 to assess the responses and residual effects of different doses of applied Diazinon and Dursban on cabbage cultivation at different growth stages. During experiment five treatments with three replications of two pesticides were applied in the experimental field. The plot size was $2 \mathrm{~m} \mathrm{X} 2 \mathrm{~m}$ and total plots were 45 for the above mentioned treatments. According to experimental procedure, at early growth stage after application of two pesticides, the growth of Cabbage was enhanced but at middle and mature growth stages were slowed down the growth. At varying growth stages after spaying of both pesticides, nutrient uptake were increased and growth was simply enhanced, at that time the concentration of different doses of Diazinon ranges from 2.159 $\mu \mathrm{g}$ l- to $9.284 \mu \mathrm{g}$ l- (Diazinon doses; $1.50 \mathrm{~L} / \mathrm{ha}, 5.00 \mathrm{~L} / \mathrm{ha}, 8.00 \mathrm{~L} / \mathrm{ha}$ and $12.00 \mathrm{~L} / \mathrm{ha}$ ); in second stage it ranges $2.823 \mu \mathrm{g}$ l- to $12.140 \mu \mathrm{g} \mathrm{l-}$ and at mature stage the concentration ranges from $2.936 \mu \mathrm{g} \mathrm{l}$ - to $12.626 \mu \mathrm{g} \mathrm{l}$ - at the respective applied doses, which is statistically significant at 0.001 level $\left(t^{3}\right.$ 12.941). On the other hand, the residual effects of Diazinon at different doses at different time line were found, which were ranges from $2.767 \mu \mathrm{g} \mathrm{l}$ - to $7.284 \mu \mathrm{g} \mathrm{l}$ - at varying time and doses of application, which is statistically significant at 0.001 level $\left(\mathrm{t}^{3} 12.941\right)$. Again, about Dursban application at different doses, where the responses of uptake by Cabbage ranges from $0.373 \mu \mathrm{g}$ l- to $5.715 \mu \mathrm{g} \mathrm{l}$ at rate of $0.50 \mathrm{~L} / \mathrm{ha} ; 1.00 \mathrm{~L} / \mathrm{ha}$; $2.00 \mathrm{~L} / \mathrm{ha}$ and $4.00 \mathrm{~L} / \mathrm{ha}$ throughout the growth stages, which is statistically significant at 0.004 level $(\mathrm{t}>3.182)$. On the other hand, the residual effects of Dursban at different doses at different time line were found, which were ranges from $0.799 \mu \mathrm{g}$ l- to $5.818 \mu \mathrm{g}$ l- at varying time and doses of application, which is statistically significant at 0.001 level $\left(\mathrm{t}^{3}\right.$ 12.941). The intangible of this experiment concluded that there was a positive response of plant uptake and residual effect on soil clearly occurs in both cases.
\end{abstract}

Keywords: Pesticide; Diazinon; Dursban; Cabbage; Residual effect and Plant uptake

\section{Introduction}

Cabbage is an important and nutritious winter leafy vegetable and is widely grown in Bangladesh mainly in Robi season. It contains a range of essential vitamins, ascorbic acid and minerals as well as small amount of protein and good caloric value Haque et al. [1]. In recent years, vegetable consumption has been increased in our country. However, the productivity of Cabbage per unit area is quite low as compared to developed countries of the world FAO [2]. The response of Cabbage is high to nitrogen application and moderate to phosphorus application Mallik \& Charya [3]; Vice \& Polach [4]. For the higher productivity, pesticides are also other major agro-chemicals that controlling pest to destroy or decaying the vegetable growth of Cabbage but unfortunately, the application of pesticides are heavily sprayed on Cabbage field as this vegetable is more prone to pest infestation. But indiscriminate use of pesticides on vegetables are considered to be a serious health hazard to human as the residues and it also affect the yield and mineral content of Cabbage Reddy et al. [5].
Organophosphorus (OP) and organochlorine (OC) pesticides are widely used in agriculture as insecticides and leave residues to varying extents in agricultural produce such as vegetables and fruits. Due to their toxic properties and potential risk to consumers, their residues in food commodities is an issue of public concern and controlled by legislation Dimitra [6]. Indiscriminate application of inorganic and organic pesticides has led to an accumulation of heavy metal and metalloid residues in many agricultural soils, dramatically reducing agricultural productivity. Soils with low levels of trace elements are frequently used for vegetable growing; accumulation of these trace elements in the edible portion of these drops can occurred and pose significant health risks once entered into the human food chain Meagher [7]; Moreno et al. [8].

The sources of these elements vary and the propensity for plants to accumulate and translocate them to edible and harvested parts depends to a large extent upon plant genotype; 
soil and climatic factors as well as crop management Stalikas et al. (1997); Moreno et al. [9,10]. Thus, inorganic and organic pesticide accumulation in soils and subsequently plant uptake of those elements under natural open field conditions is a great interest of green house or container studies may not be truly representative of field conditions Barona \& Romero [11]; Moreno et al. [9]. The experimental study conducted with assessing the response and residual effects of Diazinon and Dursban over Cabbage and its soil at different stages of accumulation.

\section{Materials and Methods}

\section{Location of Experimental site}

An experiment was conducted at Experimental Field of BCSIR, Dhaka during winter season 2008. The soil of BCSIR is belongs to Tajgaon Series, and there was no pesticide concentration found before after analysis. In this experiment Brassica Olearis $L$. variety of Cabbage was used.

\section{Experimental Design}

The total plot size was $12 \mathrm{~m} \mathrm{X} 24 \mathrm{~m}$ which required 45 small unit plots. The per unit plot size was $2 \mathrm{~m} \mathrm{X} 2 \mathrm{~m}$ which accommodated 16 plants. The experiment was carried out in a randomized Block Design (RBD) with three replications for Diazinon and Dursban pesticides. All plots were treated with basal Fertilizers for supplying plant nutrition. These fertilizers were applied during land preparation and as per standard procedures. The doses of Diazinon and Dursban pesticides were sprayed on and around plants were $1.50 \mathrm{~L} / \mathrm{ha}, 5.00 \mathrm{~L} / \mathrm{ha}, 8.00$ $\mathrm{L} / \mathrm{ha}$ and $12.00 \mathrm{~L} / \mathrm{ha}$ for Diazinon and $0.50 \mathrm{~L} / \mathrm{ha} ; 1.00 \mathrm{~L} / \mathrm{ha}$; $2.00 \mathrm{~L} / \mathrm{ha}$ and $4.00 \mathrm{~L} /$ ha for Dursban in a respective rates. Thus the different intercultural operations were applied whenever necessary.

\section{Collection, Preparation and Storage of Soil and Plant Samples}

The time of soil and plant samples were collected from experimental sites or plots due to 6 hours later after different doses of Diazinon and Dursban applied to the field then second sampling was done 30 days after first sampling and third or last sampling was done 45 days after second sampling. After each sampling time, soil and plants brought back to the Analytical Laboratory, Department of Soil, Water and Environment, University of Dhaka. The samples were taken into sun light protected non-polythene bag with well labeled to prevent exposing and contamination or alteration of organic properties. Soil samples were collected at the depth of $15 \mathrm{~cm}$ from surface.

\section{Reagents}

The organic solvents, acetonitrile, ethyl acetate used were HPLC grade and were purchased from E. Merck. Technical grade pesticide standards were obtained from Center for Advanced Research, University of Dhaka with a purity of $95-99 \%$. The standards were stored in a freezer at $-5^{\circ} \mathrm{C}$. Ultra high quality water was obtained from Milli-Q water purification system
(Millipore, Bedford, MA, USA). Mili-Q Water and acetonitrile were degassed by vacuum suction. All samples and solvents were filtered through Millipore membrane filters (Polysulfone membrane and $0.45 \mu \mathrm{m}$ pore size) before injection on the column. Anhydrous sodium sulphate for residue analysis, 1260 mesh, was maintained at $300^{\circ} \mathrm{C}$ overnight. A source of pure nitrogen was used for evaporation to dryness in the extraction step.

\section{Standard Preparation}

For preparation of stock solution, standards were dissolved in acetonitrile and four levels of intermediate standard solutions of each pesticide were prepared maintaining the same matrix concentration for the preparation of calibration curve and stored at $4^{\circ} \mathrm{C}$ in the dark. Working solutions were prepared daily by appropriate dilution with acetonitrile.

\section{Sample Preparation}

After brought to the laboratory, soil and plant samples were weighted in a field moisture condition and then kept them to air dry. Then they were mashed into $2 \mathrm{~mm}$ sized grain and they were subjected to analyses.

\section{Extraction}

Triturate a sample of $25 \mathrm{gm}$, with Sodium Sulphate to dry, powdery mixture, with the aid of an extraction thimble; extract the mixture exhaustively with Petroleum Ether in Soxhlet apparatus. Concentrate just to dryness the extract solution by a concentrator and dilute to $25 \mathrm{ml}$ with Petroleum Ether saturated with Dimethylformamide Peter \& Zeumer [12]. Edible part of each vegetable sample (75 g) was cut into small pieces and homogenized by means of a kitchen blender and kept in a freezer by wrapping with clean airtight polythene bag (zip lock) at temperature below $-15^{\circ} \mathrm{C}$. The blended Cabbage sample $(75 \mathrm{~g})$ was mixed with anhydrous sodium sulphate $(50 \mathrm{~g})$ and extracted with ethyl acetate Islam et al. [13] in a $200 \mathrm{~mL}$ conical flask using an Ultra-Turrax (IKA-WERK) for 4-5 min.

The content was allowed to settle down for about half an hour and the ethyl acetate extract was then filtered through a Buchner-funnel fitted with a filter paper covered by $20 \mathrm{~g}$ of anhydrous sodium sulphate. After filtration, the extract was evaporated to dryness and re-dissolved in $5 \mathrm{~mL}$ of acetonitrile (MeCN) and finally the volume was made up to $2 \mathrm{~mL}$ using rotary vacuum evaporator. The extract was then transferred to a graduated test tube and the final volume was adjusted at exactly $2 \mathrm{~mL}$ by adding a few drops of acetonitrile. Solutions were then centrifuged and filtered. The clean organic layers were taken and were analyzed by a high performance liquid chromatography having UV/Visible detector Mendham et al. [14], De [15].

\section{HPLC Systems}

A Shimadzu SCL-10AVP, Version 5.22 High performance liquid chromatography having UV/visible detector was used for identification and quantification of pesticides. Separation was 
performed on reversed phase C-18 column (Nova pack). Samples were injected manually through a Rheodyne injector. Detector was connected to the computer for data processing. The working condition of HPLC was binary gradient, mobile phase was acetonitrile: water; (70:30), flow rate was $1 \mathrm{~mL} \mathrm{~min}^{-1}$, injection volume was $20 \mu \mathrm{L}$ and the wavelength of the UV/visible detector was fixed at $254 \mathrm{~nm}$ for the residual analysis of Diazinon and 230 $\mathrm{nm}$ for the analysis of Dursban Mendham et al. [14].

\section{Identification and Quantification}

The compound was identified by comparing its retention time with respect to technical grade reference standard. The quantitative determination was carried out with the help of a calibration curve drawn from chromatographic experiments with standard solution. For quantification an external calibration curve with four different concentrations of each pesticide, with matrix matching were made. The standard solutions for the calibration curves were prepared in control matrix because samples may possess co extractants in the matrix which may affect the peak area of the unknown samples Mendham et al. [14].

\section{Recovery}

Recovery studies were performed to examine the efficacy of extraction and clean up. Untreated cauliflowers were spiked with known concentration of the pure pesticides standard solution of each type of pesticide and extraction and clean-up were performed as described earlier. The concentration of each pesticide in the final extracts was calculated Mendham et al. [14].

\section{Statistical Analysis}

The response and residue results were the means from three replicates of each treatment and all data's were analyzed using descriptive statistics such as regression and correlation using SPSS version 12 for windows.

Table 1: Retention Times Windows (RTWs) and typical calibration parameters of the method in Cabbage matrix.

\begin{tabular}{|c|c|c|c|c|c|}
\hline \multirow{3}{*}{$\begin{array}{c}\text { Compound } \\
\text { Diazinon }\end{array}$} & Calibration & & \multicolumn{2}{|c|}{ Calibration parameters } & \\
\hline & \multicolumn{2}{|c|}{ range RT (Min) $\left(\mathrm{mg} \mathrm{kg}^{-1}\right)$} & \multicolumn{2}{|c|}{ - } & -------R2 \\
\hline & 8.1 & $0.066-1.46$ & $1.3^{\prime} 105$ & 65000 & 0.998 \\
\hline Malathion & 5.7 & $0.080-1.66$ & $4.5^{\prime} 104$ & 43000 & 0.992 \\
\hline Chlorpyrifos & 12.9 & $0.076-1.15$ & $3.9^{\prime} 104$ & 54000 & 0.991 \\
\hline Cypermethrin & 9.8 & 0.064-0.99 & $8.27^{\prime} 104$ & 18400 & 0.988 \\
\hline
\end{tabular}

\section{Result and Discussion}

Limit of Detection (LOD) was calculated from the peak intensity at $0.1 \mathrm{mg} \mathrm{kg}^{-1}$ and blank levels in recovery tests. LOD was defined as $\mathrm{S} / \mathrm{N}>4$ so that it is in the linear range of the standard calibration. The LOD of Diazinon and Dursban was 0.02 $\mathrm{mg} \mathrm{kg}^{-1}$. Recoveries which were obtained by triplicate analysis of cauliflower sample spiked with each type of pesticide at one fortification level were satisfactory for response and residue analysis and are of the same order as those obtained by using more complicated methodologies. The percent recoveries for Diazinon and Dursban were 106.0 and 81.7, respectively. Residues were corrected according to the average of recovery. Linear calibration curves were found between peak areas and analyte concentration in the whole range studied. The linear regression $(y=a+b x)$ parameters for method calibration are shown in Table 1 . The determination coefficients $\left(\mathrm{R}^{2}\right)$ of analytical curves were near 0.99 , with linearity for each compound, which allows the quantitation of these compounds by the method of external standardization.

Table 2: Amounts of residues detected in cauliflower samples treated with the respective pesticide.

\begin{tabular}{|c|c|c|}
\hline & \multicolumn{2}{|c|}{ Residue (mg kg ${ }^{-1}$ ) } \\
\hline Dose & Diazinon & Dursban \\
\hline Recommended dose & 1.085 & 1.628 \\
\hline Double of the & & 1.64 \\
\hline Recommended dose & ND = Not detected i.e., below detection level of $0.02 \mathrm{mg} \mathrm{kg}^{-1}$ \\
\hline
\end{tabular}

Diazinon and Dursban were detected in all samples (Table 2). According to MRL Status Report [16], it is found that Diazinon was detected above Maximum Residue Limit $\left(0.01 \mu \mathrm{g} \mathrm{kg}^{-1}\right.$ of sample) in the samples where Diazinon was sprayed at the recommended dose then double of the recommended dose and higher on. The amount of the residues of Diazinon detected at 1st sampling time were $2.768 \mu \mathrm{g} \mathrm{l}^{-1}$ for $1.50 \mathrm{~L} /$ ha application whereas the Diazinon content in $1.50 \mathrm{~L} /$ ha was detected directly $6.59 \mu \mathrm{g} \mathrm{l}^{-1}, 6.455 \mu \mathrm{g} \mathrm{l}^{-1}$ for $5.00 \mathrm{~L} / \mathrm{ha}$ application whereas it was delectated directly $15.37 \mu \mathrm{g} \mathrm{l}^{-1}$; for $8.00 \mathrm{~L} /$ ha application, the residual effect was found $8.694 \mu \mathrm{g} \mathrm{l}^{-1}$ whereas $20.70 \mu \mathrm{g} \mathrm{l}^{-1}$ detected and $11.903 \mu \mathrm{g} \mathrm{ll}^{-1}$ residual content was found at 12.00 $\mathrm{L} / \mathrm{ha}$ application whereas in this application rate was detected $28.34 \mu^{-1}$ (Figure 1). The amount of the residues of Diazinon detected at $2 \mathrm{nd}$ sampling time were $1.882{\mu \mathrm{gl}^{-1}}$ for $1.50 \mathrm{~L} / \mathrm{ha}$ application; $4.390 \mathrm{\mu gl}^{-1}$ for $5.00 \mathrm{~L} / \mathrm{ha}$ application; for $8.00 \mathrm{~L} /$ ha application, the residual effect was found $5.912 \mathrm{\mu g} \mathrm{l}^{-1}$ and $8.094 \mathrm{mgl}^{-1}$ residual content was found at $12.00 \mathrm{~L} / \mathrm{ha}$ application (Figure 1). 

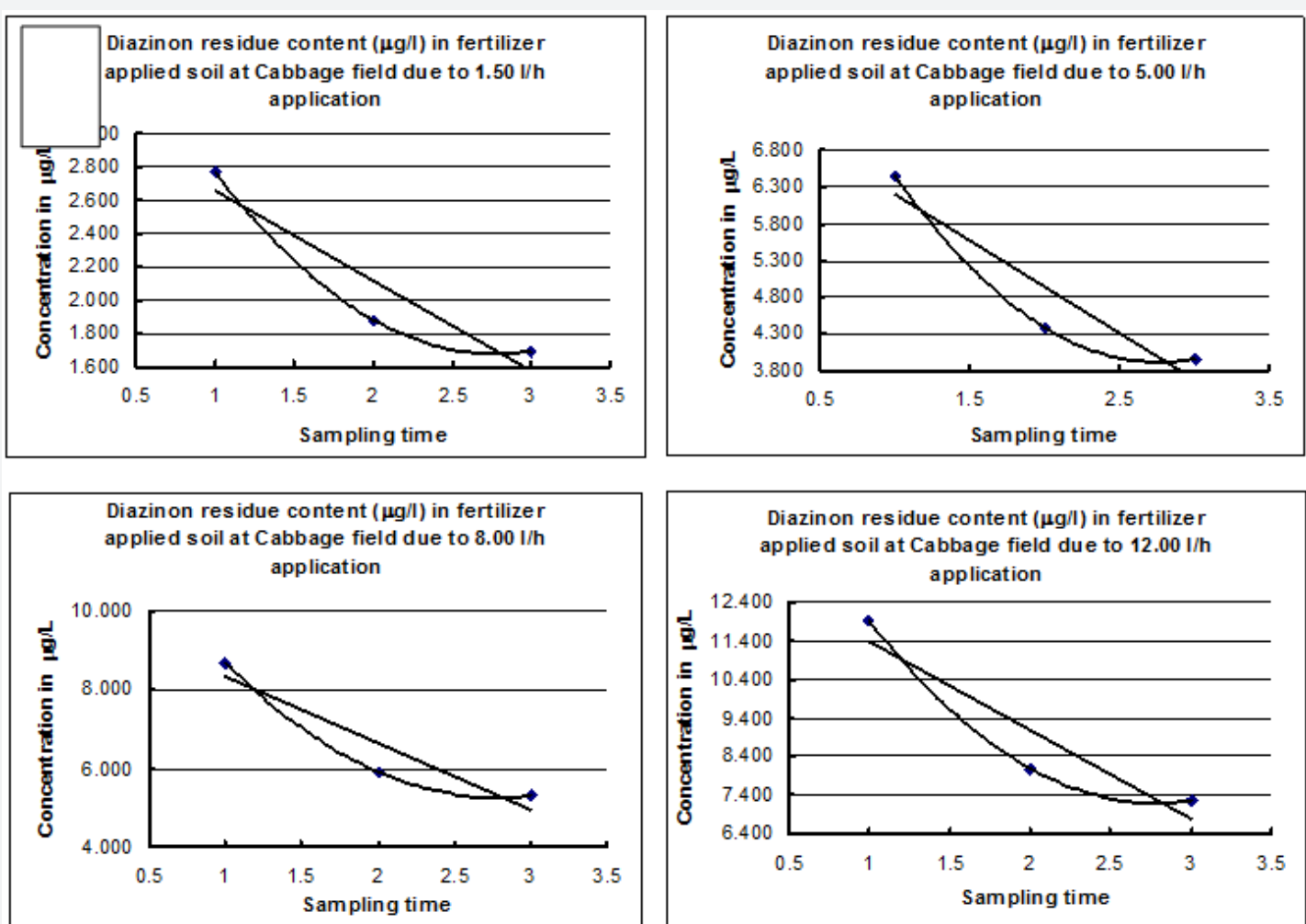

Figure 1: Diazinon residue content $\left(\mu \mathrm{g} \mathrm{l}^{-1}\right)$ at different time against different treatment doses.
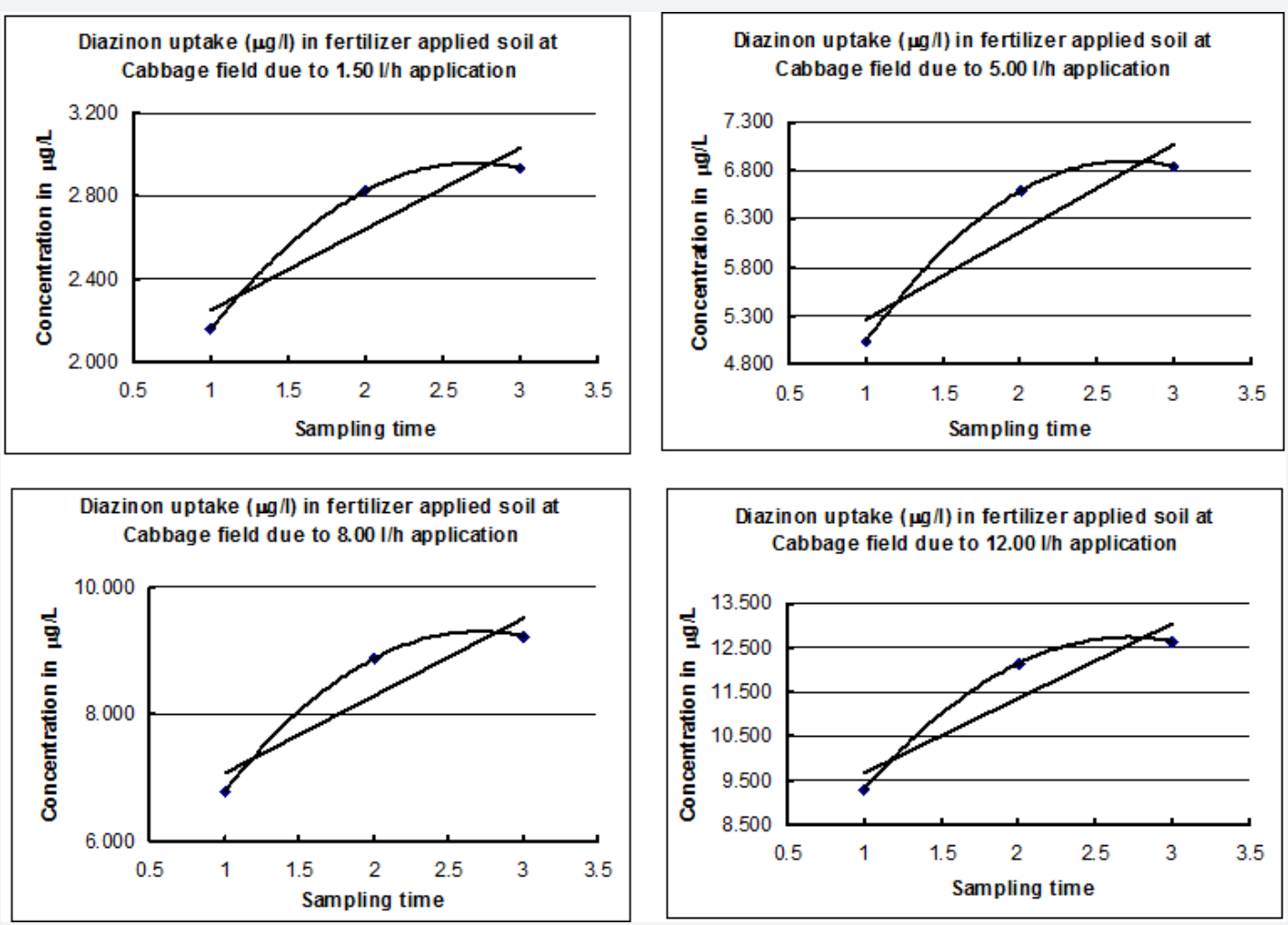

Figure 2: Diazinon uptake response $\left(\mu \mathrm{g} \mathrm{l}^{-1}\right)$ at different time against different treatment doses.

The amount of the residues of Diazinon detected at 3rd sampling time were $1.694 \mu \mathrm{g} \mathrm{l}^{-1}$ for $1.50 \mathrm{~L} /$ ha application; $3.951 \mu \mathrm{gl}^{-1}$ for $5.00 \mathrm{~L} / \mathrm{ha}$ application; for $8.00 \mathrm{~L} / \mathrm{ha}$ application, the residual effect was found $5.321 \mu \mathrm{gl}^{-1}$ and $7.285 \mu \mathrm{gl}{ }^{-1}$ residual content was found at $12.00 \mathrm{~L} / \mathrm{ha}$ application (Figure 1). The amount of the uptake response of Diazinon detected at 1 st 
sampling time were $2.159{\mu \mathrm{gl}^{-1}}$ for $1.50 \mathrm{~L} /$ ha application; 5.035 $\mu \mathrm{g}^{-1}$ for $5.00 \mathrm{~L} /$ ha application; for $8.00 \mathrm{~L} /$ ha application, the uptake response was found $6.781 \mu \mathrm{g} \mathrm{l}^{-1}$ and $9.284 \mu \mathrm{g} \mathrm{l}^{-1}$ uptake response was found at $12.00 \mathrm{~L} /$ ha application (Figure 2). The amount of the uptake response of Diazinon detected at $2 \mathrm{nd}$ sampling time were $2.82 \mu \mathrm{g} \mathrm{l}^{-1}$ for $1.50 \mathrm{~L} /$ ha application; 6.584 $\mu \mathrm{g}^{-1}$ for $5.00 \mathrm{~L} /$ ha application; for $8.00 \mathrm{~L} /$ ha application, the uptake response was found $8.867 \mu \mathrm{g} \mathrm{l}^{-1}$ and $12.140 \mu \mathrm{g} \mathrm{l}^{-1}$ uptake response was found at $12.00 \mathrm{~L} /$ ha application (Figure 2). The amount of the uptake response of Diazinon detected at $3^{\text {rd }}$ sampling time were $2.936 \mathrm{~g} \mathrm{l}^{-1}$ for $1.50 \mathrm{~L} /$ ha application; 6.847 $\mu \mathrm{g}^{-1}$ for $5.00 \mathrm{~L} /$ ha application; for $8.00 \mathrm{~L} /$ ha application, the uptake response was found $9.222 \mu \mathrm{g} \mathrm{l}^{-1}$ and $12.626 \mu \mathrm{g} \mathrm{l}^{-1}$ uptake response was found at $12.00 \mathrm{~L} / \mathrm{ha}$ application (Figure 2).

Correlations for Diazinon Treatment against Residual and Uptake in all cases were statistically significant at $1 \%$ level $(r=1.00 \& 0.99$; (Tables 3a, 3b \& 3c) and the regression for same treatment against residual and uptake were statistically significant at $0.1 \%$ level ( $\left.\mathrm{t}^{3} 12.941\right)$.

Table 3a: Correlations for Diazinon Treatment against Residual and Uptake $1^{\text {st }}$ sampling

\begin{tabular}{|c|c|c|c|}
\hline & Treatments & Residual & Uptake \\
\hline Treatments & 1 & $0.990^{* *}$ & $0.990^{* *}$ \\
\hline Residual & & 1 & $1.000^{* *}$ \\
\hline Uptake & & & 1 \\
\hline
\end{tabular}

** Correlation is significant at the 0.01 level (2-tailed).
Table 3b: Correlations for Diazinon Treatment against Residual and Uptake $2^{\text {nd }}$ sampling.

\begin{tabular}{|c|c|c|c|}
\hline & Treatments & Residual & Uptake \\
\hline Treatments & 1 & $0.990^{* *}$ & $0.990^{* *}$ \\
\hline Residual & & 1 & $1.000^{* *}$ \\
\hline Uptake & & & 1 \\
\hline
\end{tabular}

** Correlation is significant at the 0.01 level (2-tailed).

Table 3c: Correlations for Diazinon Treatment against Residual and Uptake $3^{\text {rd }}$ sampling.

\begin{tabular}{|c|c|c|c|}
\hline & Treatments & Residual & Uptake \\
\hline Treatments & 1 & $0.990^{* *}$ & $0.990^{* *}$ \\
\hline Residual & & 1 & $1.000^{* *}$ \\
\hline Uptake & & & 1 \\
\hline
\end{tabular}

** Correlation is significant at the 0.01 level (2-tailed).

Similarly According to FAO/WHO Standards [2], it is found that Dursban was detected above Maximum Residue Limit 0.05 $\mathrm{mg} \mathrm{kg}{ }^{-1}$ of sample) in the samples where Dursban was sprayed at the recommended dose then double of the recommended dose and higher on. The amount of the residues of Dursban detected at $1^{\text {st }}$ sampling time were $0.799 \mu \mathrm{g} \mathrm{l}^{-1}$ for $0.50 \mathrm{~L} / \mathrm{ha}$ application whereas the Dursban content in $0.50 \mathrm{~L} /$ ha was detected directly $1.08 \mathrm{\mu g} \mathrm{l}^{-1}, 2.131 \mathrm{\mu g} \mathrm{l}^{-1}$ for $1.00 \mathrm{~L} / \mathrm{ha}$ application whereas it was delectated directly $2.88 \mu \mathrm{g} \mathrm{l}^{-1}$; for $2.00 \mathrm{~L} /$ ha application, the residual effect was found $5.638 \mu \mathrm{g} \mathrm{l}^{-1}$ whereas $7.62 \mu \mathrm{g} \mathrm{l}^{-1}$ detected and $8.17 \mu \mathrm{g} \mathrm{l}^{-1}$ residual content was found at $4.00 \mathrm{~L} / \mathrm{ha}$ application whereas in this application rate was detected 11.05 $\mu \mathrm{g} \mathrm{l}^{-1}$ (Figure 3).
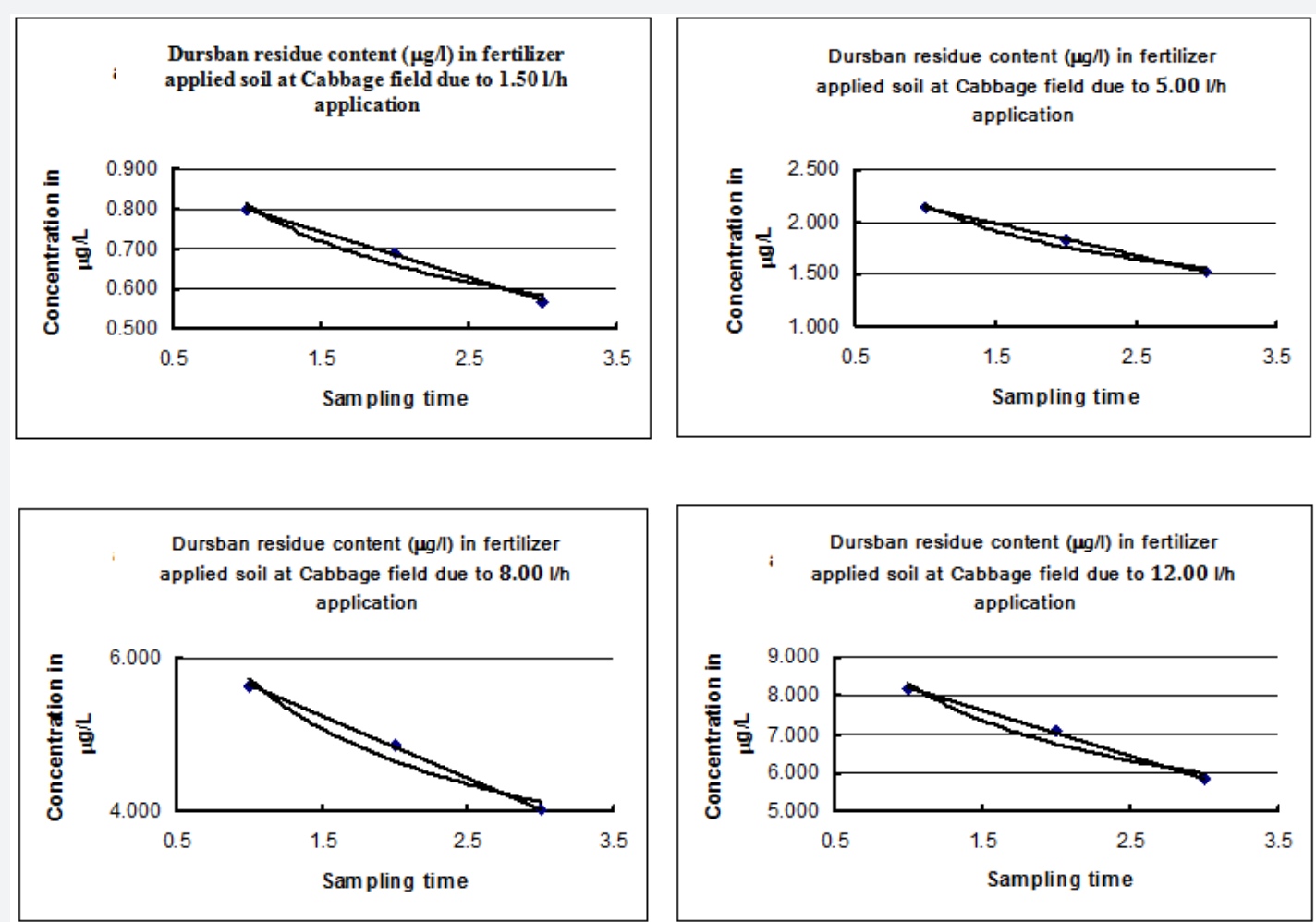

Figure 3: Dursban residue content $\left(\mathrm{mg} \mathrm{l}^{-1}\right)$ at different time against different treatment doses. 
The amount of the residues of Dursban detected at $2^{\text {nd }}$ sampling time were $0.689 \mathrm{\mu g} \mathrm{l}^{-1}$ for $0.50 \mathrm{~L} /$ ha application; 1.837 $\mu \mathrm{g} \mathrm{l}^{-1}$ for $1.00 \mathrm{~L} /$ ha application; for $2.00 \mathrm{~L} /$ ha application, the residual effect was found $4.861 \mu \mathrm{g} \mathrm{l}^{-1}$ and $7.049 \mu \mathrm{g} \mathrm{l}^{-1}$ residual content was found at $4.00 \mathrm{~L} / \mathrm{ha}$ application (Figure 3). The amount of the residues of Dursban detected at $3^{\text {rd }}$ sampling time were $0.568 \mu \mathrm{g} \mathrm{l}^{-1}$ for $0.50 \mathrm{~L} / \mathrm{ha}$ application; $1.516 \mu \mathrm{g} \mathrm{l}^{-1}$ for 1.00 $\mathrm{L} /$ ha application; for $2.00 \mathrm{~L} /$ ha application, the residual effect was found $4.012 \mu \mathrm{g} \mathrm{l}^{-1}$ and $5.818 \mu \mathrm{g} \mathrm{l}^{-1}$ residual content was found at $4.00 \mathrm{~L} /$ ha application (Figure 3). The amount of the uptake response of Dursban detected at 1 st sampling time were $0.373 \mu \mathrm{g} \mathrm{l}^{-1}$ for $0.50 \mathrm{~L} /$ ha application; $0.996 \mu \mathrm{g} \mathrm{l}^{-1}$ for $1.00 \mathrm{~L} / \mathrm{ha}$ application; for $2.00 \mathrm{~L} /$ ha application, the uptake response was found $2.636 \mu \mathrm{g} \mathrm{l}^{-1}$ and $3.82 \mu \mathrm{g} \mathrm{l}^{-1}$ uptake response was found at $4.00 \mathrm{~L} / \mathrm{ha}$ application (Figure 4).
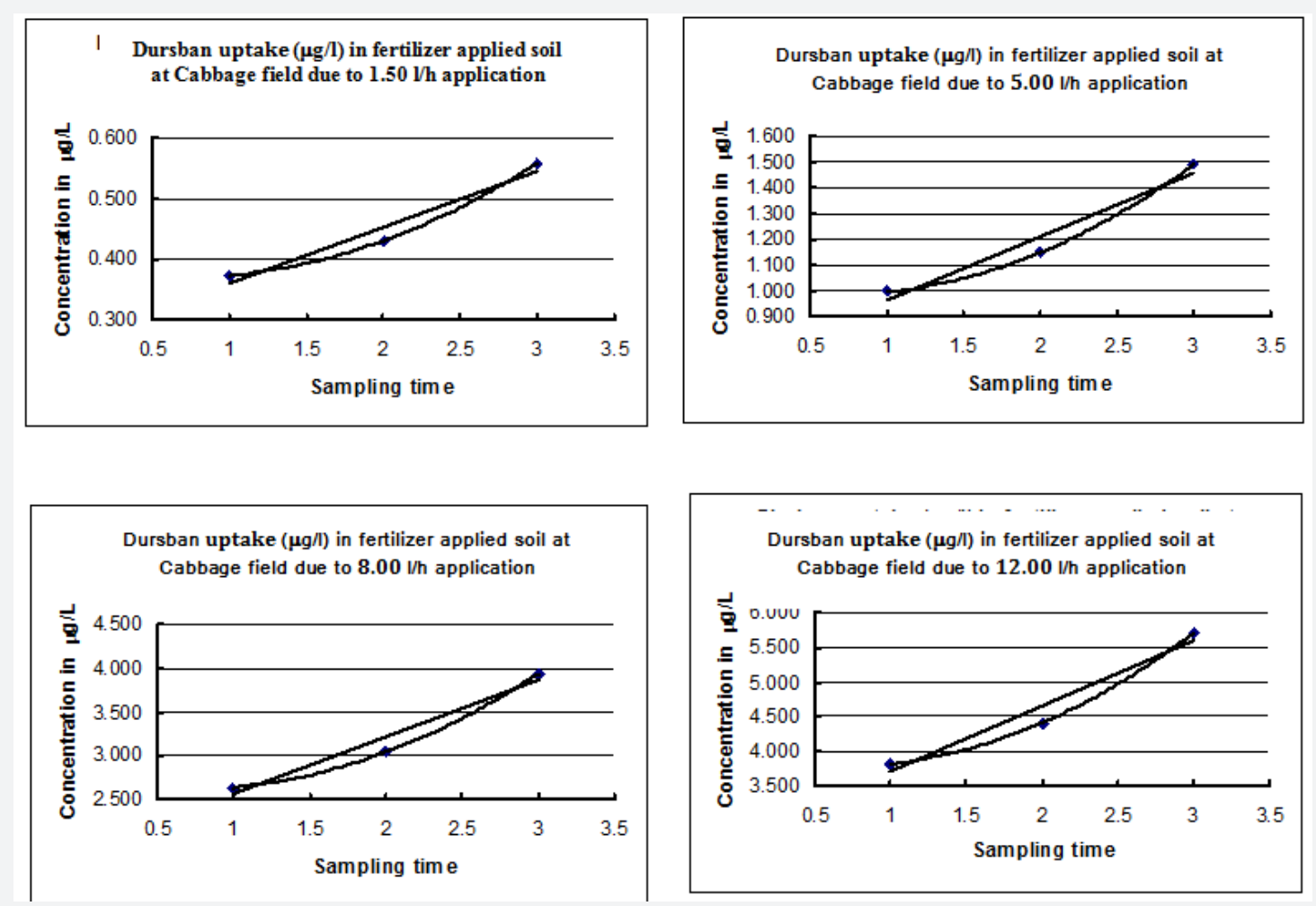

Figure 4: Dursban uptake response $\left(\mathrm{mg} \mathrm{l}^{-1}\right)$ at different time against different treatment doses.

Table 4a: Correlations for Dursban Treatment against Residual and Uptake $1^{\text {st }}$ sampling.

\begin{tabular}{|c|c|c|c|}
\hline & Treatments & Residual & Uptake \\
\hline Treatments & 1 & $0.979^{* *}$ & $0.979^{* *}$ \\
\hline Residual & & 1 & $1.000^{* *}$ \\
\hline Uptake & & & 1 \\
\hline
\end{tabular}

** Correlation is significant at the 0.01 level (2-tailed).

Table 4b: Correlations for Dursban Treatment against Residual and Uptake 2nd sampling.

\begin{tabular}{|c|c|c|c|}
\hline & Treatments & Residual & Uptake \\
\hline Treatments & 1 & $0.979^{* *}$ & $0.979^{* *}$ \\
\hline Residual & & 1 & $1.000^{* *}$ \\
\hline Uptake & & & 1 \\
\hline
\end{tabular}

** Correlation is significant at the 0.01 level (2-tailed).

The amount of the uptake response of Dursban detected at 2nd sampling time were $0.430 \mu^{-1}$ for $0.50 \mathrm{~L} /$ ha application; $1.149 \mathrm{\mu g}^{-1}$ for $1.00 \mathrm{~L} /$ ha application; for $2.00 \mathrm{~L} / \mathrm{ha}$ application, the uptake response was found $3.040 \mu \mathrm{g} \mathrm{l}^{-1}$ and $4.408 \mu \mathrm{g} \mathrm{l}^{-1}$ uptake response was found at $4.00 \mathrm{~L} / \mathrm{ha}$ application (Figure 4). The amount of the uptake response of Dursban detected at $3^{\text {rd }}$ sampling time were $0.558 \mu \mathrm{g} \mathrm{l}^{-1}$ for $0.50 \mathrm{~L} / \mathrm{ha}$ application; $1.489 \mathrm{\mu g} \mathrm{l}^{-1}$ for $1.00 \mathrm{~L} /$ ha application; for $2.00 \mathrm{~L} /$ ha application, the uptake response was found $3.941 \mu \mathrm{g} \mathrm{l}^{-1}$ and $5.715 \mu \mathrm{g} \mathrm{l}^{-1}$ uptake response was found at $4.00 \mathrm{~L} /$ ha application (Figure 4). Correlations for Dursban Treatment against Residual and Uptake in all cases were statistically significant at $1 \%$ level $r=1.00 \&$ 0.97; (Tables 4a, 4b \& 4c) and the regression for same treatment against residual and uptake were statistically significant at $0.4 \%$ level ( $\mathrm{t}>3.182)$.

Table 4c: Correlations for Dursban Treatment against Residual and Uptake 3rd sampling.

\begin{tabular}{|c|c|c|c|}
\hline & Treatments & Residual & Uptake \\
\hline Treatments & 1 & $0.979^{* *}$ & $0.979^{* *}$ \\
\hline Residual & & 1 & $1.000^{* *}$ \\
\hline Uptake & & & 1 \\
\hline
\end{tabular}

${ }^{* *}$ Correlation is significant at the 0.01 level (2-tailed). 


\section{Discussion}

Diazinon may decompose in plants in two directions. One of them may be oxidation of the phosphorothioate to the corresponding phosphate (diazinon) followed by hydrolysis of the P-X bond with the formation of non toxic diethylphosphoric acid and 2-isopropyl-4-methyl-6-0xypyrimidine and the another direction of the decomposition of diazinon may be the oxidation of the side isopropyl group of the ring with the subsequent hydrolysis of the phosphorus halogen bond with decomposition of the heterocyclic ring and the liberation of carbon dioxide gas. Diazinon is highly toxic to humans and animal. So the recommended dose which is applied by the farmer in the field to control the pests in cauliflower should be lower. Dursban may decomposes in plants and may produce chlorpyrifosoxon and 3, 5, 6-trichloro-2-pyridinol, which is further degraded to 3, 5, 6-trichloro-2-methoxypyridine and carbon dioxide Racke [17]. Dursban are highly toxic to human and animal. So, the recommended dose of the Dursban in Cabbage should be lower.

Since the organophosphorus and pyrethroid pesticides residues are not degraded into non toxic products in short period of time. They still persisted in vegetable. So the recommended dose, which is applied by the farmer in the field to control pests in cauliflower, should be lower or pre-harvest interval should be longer.

\section{Conclusion}

In Bangladesh context, the Cabbage growers have been using the pesticides frequently to have the higher and insect free yield. But the overdoses of pesticides make the residue problem, which might pollute our food and environment. Appropriate use of pesticides in agriculture needs to be addressed in Bangladesh and other countries. Although the Government is concerned about pesticide residues in the food and the environment, staff and facilities to conduct the necessary monitoring programs are not available. In addition the country is not yet established legal limits for residues and depends upon Codex allowable limit which are not always proposed for all crops and major pesticides used within the country. So in order to remove residual effect of pesticides which are toxic, we should know the exact dose which should be recommended to the farmer and the harvest time of each pesticides so that the amount of residual pesticides in vegetables might be lower than the present time. And an attractive method was provided by this approach with detection limits at parts per million concentrations and could be extended to additional crops and pesticides.

\section{References}

1. Haque KMF, AA Jahangir, ME Haque, RK Mondal, MAA Jahanb, et al. (2006) "Yield and Nutritional Quality of Cabbage as Affected by Nitrogen and Phosphorus Fertilization, Bangladesh. J of Sci Ind Res. 41(1-2): 41

2. FAO/WHO Standards (2008) Pesticide residues in food. Maximum residue limits. CODEX Alimentations.

3. Mallik SC, BB Chaya (1996) Effect of different level of nitrogen and different spacing on growth and yield. J of Environment and Ecology. 14 (2): 304-306.

4. Vice F, J Polach (1980) Effect if principal plant nutrient on cabbage yield and quality. Hort Abst 50: 535.

5. Reddy NS, S Dash, Sontakke (1997) Effects of spraying selected pesticides on the contents of specified minerals in cabbage". Plant Foods for Hum Nutr 51(4): 357-363.

6. Dimitra A, Lambropoulou, Triantafyllos A, Albanis (2003) "Headspace solid phase micro-extraction in combination with gas chromatographymass spectrometry for the rapid screening of organophosphorus insecticide residues in strawberries and cherries. J of Chromatography A 993: 197-203.

7. Meagher RB (2000) Phytoremediation of toxic element and organic pollutants. Curr opin Plant Biol 3: 153-162.

8. Moreno DA, G Villora, J Hernandez, N Castilla, L Romero (2002) Accumulation of $\mathrm{Zn}, \mathrm{Cd}, \mathrm{Cu}$ and $\mathrm{Pb}$ in Chinese Cabbage as influenced by climatic conditions under protected cultivation. J Agric Food Chem 50: 1964-1969.

9. Moreno DA, LR Lopez-Lefebre, G Villora, JM Ruiz, L Romero (2001) Floating row covers affect $\mathrm{Pb}$ and $\mathrm{Cd}$ accumulation and antioxidant status in Chinese cabbage. J of Sciebtia Horticulturae 89: 83-90.

10. Moreno DA, G Villora, J Hernandez, N Castilla, L Romero (2002) Floating row covers affect molybdenum and nitrogen status in Chinese cabbage grown in under field conditions. J of Functional Plant Biology 29(7): 585-593.

11. Barona A, F Romero (1997) "Relationships among metals in the solid phase of soils and in wild plants. J of Water, Air and Soil Pollution 95(14): 59-74.

12. Peter H, H Zeumer (1987) Manual of pesticides residue Analysis", vol I, working group "analysis". Pesticide commission, VCH, Germany, pp. 298-319.

13. Islam S, MS Hossain, N Nahar, M Mosihuzzaman, MIR Mamun (2009) Application of high performance liquid chromatography to the analysis of pesticide residues in Eggplants. J of Applied Sci 9: 973-977.

14. Mendham J, RC Denney, JD Barnes, MJK Thomas (2007) "VOGEL'SText Book of Quantitative Chemical Analysis" Pub. (6 $6^{\text {th }}$ edn), Pearson Education Limited. pp. 317-337.

15. MRL Status Report (2009) Agri business systems international.

16. De AK (2000) "Environmental Chemistry" Pub: New age international Ltd. ( $4^{\text {th }}$ edn), New Delhi, India. pp. 99-100.

17. Racke KD (1993) Environmental fate of chlorpyrifos. Rev Environ Contam Toxicol131: 1-150. 

(C) This work is licensed under Creative BY

DOI: 10.19080/IJESNR.2017.04.555648
Your next submission with Juniper Publishers will reach you the below assets

- Quality Editorial service

- Swift Peer Review

- Reprints availability

- E-prints Service

- Manuscript Podcast for convenient understanding

- Global attainment for your research

- Manuscript accessibility in different formats

( Pdf, E-pub, Full Text, Audio)

- Unceasing customer service

Track the below URL for one-step submission https://juniperpublishers.com/online-submission.php 